УДК 37.013

DOI 10.18413/2712-746X-2020-45-1-172-182

\title{
КОНЦЕПТУАЛИЗАЦИЯ ЧЕЛОВЕКА ЦЕЛОСТНОГО В ХРИСТИАНСКОЙ ФИЛОСОФИИ (К РАЗМЫШЛЕНИЯМ ЕПИСКОПА ФЕОФАНА (ГОВОРОВА))
}

\section{CONCEPTUALIZATION OF A HOLISTIC MAN IN CHRISTIAN PHILOSOPHY (TO THE THOUGHTS OF BISHOP THEOPHANES (GOVOROV))}

\author{
П.А. Ольхов, И.В. Гончаренко \\ P.A. Olkhov, I.V. Goncharenko
}

\begin{abstract}
Белгородский государственный национальный исследовательский университет,
Россия, 308015, г. Белгород, ул. Победы, 85

Belgorod National Research University,

85 Pobeda St, Belgorod, 308015, Russia

E-mail: eigor1@yandex.ru, olkhov@bsu.edu.ru
\end{abstract}

\begin{abstract}
Аннотация
Исследование трудов епископа Феофана (Говорова) в контексте интеллектуальной истории ХІХ в. позволяет характеризовать его стиль мышления как холистичный, дефрагментирующий философские, богословские и естественнонаучные суждения о человеке в общей связи с христианской традицией - патристическими представлениями, ученой премудростью и аскетической практикой христианского совершенствования. Авторы предполагают причастность епископа Феофана к пока что малоизученному в России антропологическому движению (teologia anthropologica), поддержанному в начале XIX в. в энциклопедическом круге митрополита Филарета (Дроздова). Проведенный анализ дает возможность трактовать антропологические установки епископа Феофана в связи с платоническими началами русского философскорелигиозного самосознания, укорененного в доктринальном исповедании восточной христианской традиции. Отмечено, что представление о человеке целостном в трудах епископа Феофана дает себя знать в его толкованиях причастности человека к Божественному и Сверхъестественному (в теофании и теозисе). Человек целостный, в понимании епископа Феофана, не только онтологически возможен, но и вечно нов: мыслитель трактует его индивидуальность как принципиально неодинокую, личностную, возрождаемую и возрождающуюся в общности (экклезиально), собственным устремлением и в соединении с нетварными Божественными энергиями приобщающуюся к Логосу. Сделан вывод о том, что обстоятельные размышления епископа Феофана о человеке целостном продуктивно соотносятся с современными проблемами философско-религиозной (христианской) антропологии и перспективами их решения.
\end{abstract}

\begin{abstract}
The character of thinking of Bishop Theophanes is primarily practice oriented, integrated patristic ideas about a person, learned wisdom and the ascetic practices of Christian cultivation. A study of the works of the Russian thinker allows us to characterize his thinking style as conceptually holistic, defragmenting philosophical and anthropological reflections on a person in the context of the intellectual history of the XIX century as well as of Christian tradition. This makes possible to understand that the thought of Bishop Theophanes is involved in a little studied anthropological movement (teologia anthropologica) perceived in the encyclopedic circle of Metropolitan Filaret (Drozdov) at the beginning of the 19th century. The analysis allows us to interpret the anthropological attitudes of Bishop Feofan in connection with the holistic Platonism of Russian philosophical and religious identity rooted in the doctrinal confession of Eastern Christian tradition. The concept of a holistic man in the writings of Bishop Feofan is manifested in his interpretations of man's involvement in the Divine and Supernatural (theophany and
\end{abstract}


theosis). A holistic man is not only ontologically possible, but forever new: the thinker interprets his individuality as fundamentally unequal, personal, reborn in community (ecclesially) and communicating with the Logos by his own aspiration in conjunction with the uncreated Divine energies. The thorough thoughts of Bishop Feofan about a holistic man are productively correlated with the contemporary problems of philosophical and religious (Christian) anthropology and the prospects of their solutions.

Ключевые слова: философско-религиозная антропология, христианская философия, индивидуальность, личность, общение, кеносис, экклесия.

Keywords: philosophical and religious anthropology, Christian philosophy, individuality, personality, communication, kenosis, ecclesia.

Постановка и исследование антропологических проблем занимают существенное место в современной христианской (православной) философии [Дронов, 1998; Вальверде, 2000; Доброхотов, 2000; Новиков, 2000аб, 2001; Хоружий, 2001; Иоанн (Зизиулас), 2002; Корольков, 2005; Скола, 2005; Мефодий (Зинковский), 2014; Чурсанов, 2014; Yannaras, 2012]. В отечественном познавательном опыте это связано, прежде всего, с обращением к наследию мыслителей XIX - начала XX вв. Определяя содержательную специфику русской философии того времени, В.В. Зеньковский указывал на ее повсеместный антропоцентризм: «Русская философия не теоцентрична (хотя в значительной части своих представителей глубоко и существенно религиозна), ...не космоцентрична (хотя вопросы натурфилософии очень рано привлекали к себе русских философов), - она больше всего занята темой о человеке, о его судьбе и путях...» [Зеньковский, 1991a, с. 16] ${ }^{1}$.

Актуализация антропологического достоинства русской христианской мысли предполагает внимание к ее холистической доминанте - установке на поиск «синтетического единства всех сторон реальности» [Зеньковский, 1991а, с. 17] ${ }^{2}-$ и, соответственно, означает необходимость интенсификации междисциплинарных исследований. Русская философия никогда не была замкнутой в себе, исключительной сферой интеллектуальной деятельности, но возникала и развивалась на границах различных дисциплин, в некотором открытом целом общего познавательного движения, - часто оказываясь «энергийной» или «синергийной антропологией» ${ }^{3}$.

Специального исследовательского внимания здесь требует «богословское человекословие» (teologia anthropologica) XIX в., которое возникало и развивалось в принципиально междисциплинарной позиции и вместе с тем все еще является наименее изученным [Goncharenko et al., 2019]. Интегральной фигурой здесь является епископ Феофан (Говоров), оставивший после себя обширное интеллектуальное наследие, анализ и уточнение антропо-

${ }^{1}$ О наиболее существенных тематико-антропологических предпочтениях в истории русской философии см. [Зеньковский, 1991a, б, в, г; Ермичев, 2014, с. 686-708; Клеман, 1992; Гаврюшин, 1997].

${ }^{2}$ Ср.: «В восприятии тогдашних поколений религия опознавалась, прежде всего, именно как возврат к цельности, как собирание души, как высвобождение из того тягостного состояния внутренней разорванности и распада, которое стало страданием века» [Флоровский, 1991, с. 250]. Как отмечал О.В. Аптекман, один из участников «хилиастического похода» 70-х годов XIX в., «то была подлинная драма растущей и выпрямляющейся души, то были муки рождения больших дум и тревожных запросов сердца <.. > я видел не раз как молодежь, отправлявшаяся уже в народ, читала Евангелие и горько рыдала над ним. Чего она искала в Евангелии?.. Какие струны ее души были так задеты "Благой вести" ?.. Крест и фригийская шапка!.. Но это было, было! У всех почти находим Евангелие» [Флоровский, 1991, с. 294].

${ }^{3}$ Одна из первых книг, где концептуально уточнялось понятие синергийной антропологии: С.С. Хоружий. «После перерыва. Пути русской философии» [1994]. 
логических смыслов которого далеки от завершения [Ширяев, 2001-2003; Тертышников, 2008; Хохлова, 2011; Алексенко, 2016; Корнилий (Зайцев), 2016; Никулина, 2016].

\section{Тринитарная семантика христианской антропологии}

Особого рода целостная антропологическая установка в русской философии появилась благодаря устремленности к опыту и доктринальным основаниям восточной христианской традиции, патристике и византийскому исихазму ${ }^{1}$. Эта установка означала несводимость проблемы человека в некий рациональный контур философского знания; как отмечает С.С. Хоружий, здесь прежде всего давало себя знать общее понимание уникальной внутренней жизни всякого человека и его непременной вовлеченности в жизнь общественную. ${ }^{2}$

В XIX веке, почти полным ровесником которого был епископ Феофан (1815-1894), установка на понимание человека в его деятельной полноте находит свое проявление в довольно интенсивном развитии диалога между академическим богословием и философией в общем пространстве христианской мысли.

Инициатором этого процесса в России стал один из самых крупных русских интеллектуалов первой половины XIX в., хорошо известный своими новаторскими, исследовательскими и издательскими проектами и ныне чтимый Русской Православной Церковью в качестве своего святителя митрополит Филарет Дроздов. Во многом благодаря его исследованиям происходит выведение концепта theologia naturalis (естественное откровение) из тандема c thelogia revelata (Божественное откровение) за рамки богословских наук ${ }^{3}$. Практики познания, характерные для theologia naturalis, уходят на второй план, но зато уточняются рациональный характер христианской мысли, мистико-аскетические восприятия Бога, мира и человека, практики личного общения, которые предполагают единство разума и веры в целостном опыте Богообщения. Благодаря познавательному подвижничеству епископа Иннокентия (Борисова), ректора Киевской духовной академии, начинается и активная разработка экклесиастических, общностных аспектов христианской антропологии [Сухова, 2010]. А.С. Хомяков, мыслитель вне клира, в исторически первой, свободной от заимствований и влияний как со стороны католического, так и со стороны протестантского богословий работе «Церковь одна» полагает необходимым рассматривать общность христиан как живой мистико-органический опыт ${ }^{4}$ [Хомяков, 1995, с. 39-40]. Проблемати-

1 «Патристика и византийский исихазм, ... способствовали выработке основных антропологических положений в рамках метафизики веры, становлению нового типа духовного познания, основанного на вере, приводящего, в свою очередь, к формированию духовной личности» [Нижников, 2012, с. 245].

${ }^{2}$ См.: «Индивидуально-личное начало приемлется и допускается исключительно в рамках службы обществу» [Хоружий, 2003]. Ср.: [Зеньковский, 1991a, с. 16-17], Разумеется, человеческая личность не мыслится в разрыве от бытия Сверхъестественного: «...если нет Бога как Лица, а есть только "божественное", то нет ... и лица в человеке» [Флоровский, 1922].

${ }^{3}$ Синтез концептов theologia naturalis - thelogia revelata разрабатывался на Западе протестантским богословом Иоганном Музеусом и получил дальнейшее развитие в трудах Дж. Локка и Х. Вольфа. В Россию связка этих терминов приходит через богословие митр. Платона (Левшина). Митр. Платон любил пользоваться латинской терминологией и потому часто обращался к ней. Митрополит Филарет (Дроздов), который также не был равнодушен к латинской терминологии, отделяет исследования theologia naturalis - thelogia revelata друг от друга: «...поскольку эта часть получила уже свое непременное место в круге наук философских... то, чтобы без нужды не умножались отрасли наук богословских, ... наставник должен только по обстоятельствам обращаться к свету природы для того, чтобы тем утвердить веру в свет Откровения» [Святитель Филарет (Дроздов), 1885, с. 123].

${ }^{4}$ По слову Н. А. Бердяева, «вечно помнить будут Хомякова прежде всего за его постановку проблемы Церкви и за его попытку раскрыть существо Церкви. Церковь - прежде всего живой 
зацию антропологических аспектов экклесиологии мы находим в работах «Чтения о Богочеловечестве» В.С. Соловьева [1989], «Столп и утверждение истины» П.А. Флоренского [2002] и многих других.

Постановка антропологических вопросов епископом Феофаном происходит в широком философско-богословском контексте. Труды «Что есть духовная жизнь и как на нее настроиться», «Путь ко спасению», «Начертание христианского нравоучения» становятся ключевыми в предлагаемой разработке проблемы христианской индивидуальности, ее жизненного, духовного формирования и становления - раскрытия учения о Церкви в свете личного теозиса [Святитель Феофан, 2009]. Мерой здесь прежде всего оказывается молитвенное сосредоточение - первичный опыт обращения к Божеству, встречи с Ним. («Молитва - самое действенное средство в духовной жизни, и вместе мера ее» [Святитель Феофан, 1997, с. 78]). Человек, существо сотворенное и творящее, способен аккумулировать и утрачивать те Божественные, благодатные энергии ${ }^{1}$, которые имманентны всему творению. «Дела любви, особенно в том смысле, как требует Господь, то есть чтобы являть любовь к врагам, требуют жертв - неизбежно. Как это может подрывать энергию нашу, слабую всегда, то для воодушевления нас Апостол выставляет жертву, которую Христос принес за нас» [Святитель Феофан, 2004, с. 480].

Экклесиология еп. Феофана имеет черты экзистенциального характера. «Мы, все верующие - тело Христово. Христос же Господь есть Глава сего тела. Как в теле всякий член живет не своею, а общею всему телу жизнью и, если отделится от тела, умирает и истлевает, так и ни один верующий не живет особняком, но живет общею всего сонма верующих, или всей Церкви, жизнью, и если отделится от них или обособится, замирает духовно и погибает» [Святитель Феофан, 2007a, с. 85]. Церковь - весьма устойчивое сообщество: христианская индивидуальность в этом сообществе проясняется и уточняется как личностно неповторимая, пребывающая в свободном и неразрывном, жертвенно возобновляемом «ядерном» синтезе с Тем, Кто посреди общности христиан: «Господь - глава Церкви. Церковь - тело Его. Одна глава, одно и тело. Кто не с телом, тот и не с главою. Это тело из всех верующих слагается, с собою живо соединенных» [Святитель Феофан, 2008b, с. 671]. Но устойчивость Церкви не есть ее автономное сущностное отличие; напротив, само ее предназначение может быть осмыслено и оправдано в жизненной перспективе человека, поврежденного в своей свободе, нарушившего или нарушающего свою исконную целостность в некотором опасном жизненном повторе. Это экзистенциальная установка умной веры ${ }^{2}-$ «ума, покорного истине Божией» [Святитель Феофан, 2007b, с. 230], обретающего таким образом всецело жизненную, в том числе философскую устойчивость. «Совокупность истин веры есть самая стройная, возвышенная, утешительная и воодушевительная философия, система настоящая, какой не представляет ни одна система философии. Только до созерцания сей системы нельзя взойти вдруг. Надо принимать истину за истиною чисто, как преподается, без суемудрия, и слагать их в сердце... когда соберутся все истины, тогда сознание, молитвою изощренное, узрит строй их и будет ими наслаждаться. Эта премудрость от века сокровенная!» [Святитель Феофан, 2007b, с. 230-231].

Осмысление человеческой природы в трудах епископа Феофана имеет сложную тринитарную семантику. Несводимая к безличным закономерностям, человеческая природа дает себя знать в ситуациях энергийного сплочения людей, прокладывающих свой жизненный путь, находящихся в активном самопоиске - возвращении утраченной целост-

организм, единство любви, прежде всего свобода несказанная, истина веры, не поддающаяся рационализации» [Бердяев, 2007]. Ср. напр.: [Владимир (Сабодан), 1997].

${ }^{1}$ Общераспространенное понимание: «Благодать [древнегреч. $\left.\chi \alpha ́ \rho ~ \varsigma\right]$, нетварная Боже-

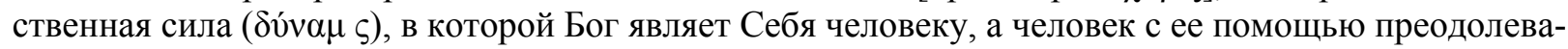
ет в себе греховное начало и достигает состояния обожения» [Иванов, 2000].

${ }^{2} \mathrm{Cp}$.: «Войдите, братие, умною верою вашею в созерцание сего порядка домостроительства Божия». [Святитель Феофан, 2010b, с. 18] 
ности с Божеством, обожении (теозисе), которое требует соответствия триипостастному единству Божества, уверенно различимому только в ситуации единства, слитности с Ним. Возможность такой ситуации обеспечивается в опыте свободного и любящего участия человека в своем близком и Божественном прообразе. Для епископа Феофана антропологически важно различить этот опыт как искреннее и деятельное самопонимание человека в отзывчивом единстве умной веры, мышления, распознающего свою ограниченность, заботы о другом. Речь идет о семантике «благодатного возрождения» (курсив наш. - Авт.) [Святитель Феофан, 2008а, с. 192] - через активную перемену ума, обретение им сознания своей целостности, или иначе, перспективы рождения «совершенно новым... через приобщение ко Христу, единому истинному источнику истинно человеческой жизни, и через облечение в образ... нового родоначальника истинных людей» [Святитель Феофан, 2008а, c. 192-193]. Благодатное возрождение человека, его рождение от Бога, означает, что «он приемлет область быть чадом Божиим (Ин 1: 12-13) ради Господа Иисуса Христа преискренне приобщившихся плоти и крови и соделываюшего верующих причастниками Божеского естества (2 Пет 1:4), которые... водятся духом Его, суть сынове (Рим 8:14), принявшие духа сыноположения, ко которому вопиют: Авва Отче (Рим 8:14), - который спослушевает духу их, что они суть сынове (Рим 8:16)» [Святитель Феофан, 2008а, с. 193].

Экзистенциальные философско-богословские аргументы в антропологии епископа Феофана образуют некий практический сплав, выверяются и упрочиваются через систематическое пропедевтическое обращение к исихастическому опыту сосредоточения на общении как условии возможности человеческой природы ${ }^{1}$. Энергийные смыслы мистико-аскетической традиции позволяют очертить сущее человека как его деятельную субстантивность. Понимание отношений Бога и человека в категориях энергии есть особый вид философско-богословской рефлексии, характеризующий живой опыт общения между Богом и человеком, - своего рода уразумевание деятельной или встречной событийности Божественных и человеческих энергий. Индивидуальное и экклезиальное здесь не растворяется в Божественном, но сорастворяется Ему и опознает таким образом свой личностный предел.

\section{Участь человека (альтернативы)}

Новые горизонты человеческого существования открываются в Боговоплощении, самоумалении (кенозисе) Божества - событии, которое не сводимо к некоторому внешнему по отношению к живущему человеку сакрально-мифологическому прошлому. Жить ли в безучастном к Божеству мире познавательно опьяняющего, всепоглощающего историзма, «в ослеплении буйствующем», «преследующем все святое и всех святых» и при этом самохвальном, самосвятном мире, «одна любовь к которому есть вражда на Бога и друг коего есть враг Божий (Иак 4:4)» [Святитель Феофан, 2010a, с. 249]? Или предпочесть мир экзистенциального трезвения, историчной веры - «зародышевым» [Святитель Феофан, 2010a, с. 445] образом сохраняющегося в природе человека триипостасного Божества, воссоединяясь с Ним вплоть до личностно уникального и экклесийного, сугубо не овнешняемого события Божественной Евхаристии - предельного соучастия в жизни Христа, пребывающего «посреде нас» (Откр 3:20)? Для человека нового, возрожденного, принадлежащего области святых и Бога как прежде всего усыновленного выбор очевиден. «В чувстве сего сыновства они наслаждаются благоволением Божиим, исполняются любовию к Богу и из любви ревнуют о славе его. Все Божеское есть как бы их собственное»

${ }^{1}$ В.Н. Лосский о характере отношений Бога и человека посредством общения пишет: «Созерцание благ будущего века, божественных реальностей, нетварного света есть не цель исихаста, но выражение общения с Богом, Которого он непрестанно взыскует» [Лосский, 2003, с. 50]. 
[Святитель Феофан, 2010a, с. 251]. Именно в этой любви возрожденный человек исцеляется от травм неполноты своего существования, откликается на призыв: «Будте святы, яко же Я свят» (1 Пет. 1:16).

Особенностью нового, возрожденного Божественной благодатью человека является стремление постоянно творить доброе. Это добро направлено как по отношению к Богу, так и по отношению к ближнему. Своего рода энергийная формула - «хождение в делах благих»: «... по исполнении времен созданы во Иисусе Христе на дела благая, да в них ходят (Еф. 2:10) и действительно ходят в обновлении жизни, по подобию светлости воскресшего Господа (Рим. 6:4), как ревнители добрым делом (Тит. 2:14)» [Святитель Феофан, 2010a, с. 251].

Епископ Феофан указывает на то, что и человек, избегающий встречи со своей жизненной глубиной, не остается один, но это неодиночество глумления над другими и собою, неодиночество сумеречного, томительного сообщества людей, не сообщающихся в своем существе, не породненных в своей полноте, живущих по своей воле в «области сатаны мрачной» [Святитель Феофан, 2010a, с. 249]. Как раз этому мнимому сообществу альтернативна общность породнившихся с Богом - «род избран, царское священство, язык свят, людей обновления» [Святитель Феофан, 2010а, с. 251]; «... все созиждутся во храм духовен, ..., созидаются в жилище Божие духом, в Церковь Святую о Господе (Еф. 2:2122)» [Святитель Феофан, 1898, с. 239].

Являясь, без сомнения, мыслителем восточного (платонизирующего) христианского склада, епископ Феофан концептуализирует человека целостного в его экзистенциальной и деятельной, энергийной очевидности - через обращение к базовым феноменам человеческого существования (свободы, умной веры, любви, неодиночества и др.). Собственно человеческая природа, ее неповторимо индивидуальные и общные смыслы проясняются им в тринитарной семантике обретения человеком своего богосыновства, в мистико-рациональном единстве самоумаления и обожения. Толкуя возможности реализации энергийных начал человеческой природы, епископ Феофан трактует альтернативы жизненного пути принципиально свободного человека - входить в полноту устойчивого сообщества соделателей, экклесию, Церковь Божию либо избирать в качестве альтернативы неустойчивое сообщество не сознающих себя в своих границах индивидуально действующих. Епископ Феофан особенно отмечает несводимость этого выбора к рациональным теоретическим моделям. Дело идет о неподрасчетном в конечном счете единстве усилий человека, который стремится обрести себя в некотором искреннем максимуме самопонимания, самосознания, дающего себя отчет в единстве оснований своего духовного опыта, событийном или встречном характере своего самопознания как Богопознания умной веры, отзывчивого мышления и заботы о другом.

Перспективным, думается, будет дальнейшее исследование концепции человека целостного как в дискуссионной перспективе русской христианской антропологии ХХ в., далеко не единомысленной в понимании целостности человеческого существования, так и в контекстах философско-антропологической герменевтики, часто предпочитающей холистической установке осмысление трансцедентальных, диалектико-онтологических или психологических смыслов жизненных альтернатив христианства ${ }^{1}$. Тем самым могут проясниться не только основания, преимущества или издержки энергийной антропологии, но, возможно, возникнет и иной познавательный эффект - большей ясности в отношении перспектив хри-

\footnotetext{
${ }^{1}$ Характерен диалектико-рационалистический поворот Л.П. Карсавина: «Тварь не личное бытие; но в своем Богопричастии, которое и есть ее бытие, в обожении своем лицетворится; в личном же бытии своем, т. е. в самом Логосе, тварь противостоит Богу» [Карсавин, 1992, с. 191].
} 
стианского мышления нашего времени после «после истории», когда жизненные ресурсы христианской философии опознаются заново, и с особенным драматизмом - в России.

\section{Список литературы}

1. Алексенко О.В. 2016. Интерпретация свт. Феофаном Затворником антропологии св. апостола Павла. М., 215 с.

2. Бердяев Н.A. 2007. Алексей Степанович Хомяков. URL: https://www.litres.ru/nikolayberdyaev/aleksey-stepanovich-homyakov/chitat-onlayn/page-4/ (дата обращения: 30 ноября 2019).

3. Вальверде К. 2000. Философская антропология. Пер. с исп. Г. Вдовиной. Под ред. Е. Гейнрихса. М., Христианская Россия: 412 с.

4. Владимир (Сабодан), митрополит Киевский и всея Украины. 1997. Экклезиология в отечественном богословии. К., 512 с.

5. Гаврюшин Н.К. 1997. Русская религиозная антропология. Том 1. URL: https://azbyka.ru/otechnik/antropologiya-i-asketika/russkaja-religioznaja-antropologija-tom-1/ (дата обращения: 18 декабря 2019).

6. Доброхотов А.Л. 2000. Философия и христианство. Сборник докладов конференции «Христианство и философия». М., Отдел религиозного образования и катехизации РПЦ: 5-21.

7. Дронов Михаил, протоиерей. 1998. Экзистенция и опыт в православном мышлении накануне XXI века. Альфа и Омега, 4: 255-271.

8. Ермичев А.А. 2014. Имена и сюжеты русской философии. СПб., Наука: 710 с.

9. Зеньковский В.В. 1991а. История русской философии. Т. 1. Ч. 1. Л., Эго.: 221 с.

10. Зеньковский В.В. 1991б. История русской философии. Т. 1. Ч. 2. Л., Эго: 280 с.

11. Зеньковский В.В. 1991в. История русской философии. Т. 2. Ч. 1. Л., Эго.: 256 с.

12. Зеньковский В.В. 1991г. История русской философии. Т. 2. Ч. 2. Л., Эго.: 269 с.

13. Иванов М.С. Благодать. В кн.: Православная энциклопедия. 2000. Под общей редакцией Патриарха Московского и всея Руси Кирилла. М., Церковно-науч. центр «Православная энциклопедия». URL: http://www.pravenc.ru/ (дата обращения: 19 ноября 2019).

14. Иоанн (Зизиулас), митрополит Пергамский. 2002. Личностность и бытие. Перевод с английского С. Чурсанова. М., Православный Свято-Тихоновский богословский институт, 10: 22-50.

15. Карсавин Л.П. 1992. Религиозно-философские сочинения. Т.1. М., Ренессанс: 325 с.

16. Клеман О. 1992. Личность по учению русских философов XIX-XX веков. Православная община, 6 (12): 52-62.

17. Корнилий (Зайцев), иеромонах. 2016. Учение святителя Феофана, Затворника Вышенского, о душе человека в контексте православной антропологии. Сергиев Посад: 28 с.

18. Корольков А.А. 2005. Духовная антропология. СПб., Изд-во СПбГУ: 323 с.

19. Лосский В.Н. 2003. Боговидение. Перевод с французского В.А. Рещиковой М., Издательство АСТ: 64 с.

20. Мефодий (Зинковский), иеромонах. 2014. Богословие личности в XIX-XX вв. СПб., Издательство Олега Обышко: 320 с.

21. Нижников С.А. 2012. Метафизика веры в русской философии. М., ИНФРА-М: 313 с.

22. Никулина Е.Н. 2016. Антрополого-педагогические воззрения святителя Феофана Затворника: автореферат дис. ... кандидата педагогических наук. М., 31 с.

23. Новиков Д.В. 2000а. Христианское учение о человеке. Человек, 5: 116-126.

24. Новиков Д.В. 2000б. Христианское учение о человеке. Человек, 6: 97-108.

25. Новиков Д.В. 2001. Христианское учение о человеке. Человек, 1: 119-127.

26. Святитель Феофан Затворник. 2008а. Воплощенное домостроительство. Опыт христианской психологии в письмах. М., Правило Веры: 462 с.

27. Святитель Феофан Затворник. 1997. Наставления в духовной жизни. М., Отчий дом: $104 \mathrm{c}$.

28. Святитель Феофан Затворник. 2010а. Начертание христианского нравоучения. М., Правило веры: 689 с.

29. Святитель Феофан Затворник. 2007а. Письма о разных предметах веры и жизни. Собрание писем. М., Правило веры: 592 с.

30. Святитель Феофан Затворник. 2007b. Письма о христианской жизни. М., Правило веры: 448 с. 
31. Святитель Феофан Затворник. 2004. Послание святого апостола Павла к Ефесянам. М., Правило Веры: 644 с.

32. Святитель Феофан Затворник. 2005. Православие и наука. Руководственная книга изречений и поучений. Составил игумен Феофан (Крюков). М., Даниловский благовестник: 680 с.

33. Святитель Феофан Затворник. 2008b. Рукописи из кельи. М., Правило Веры: 700 c.

34. Святитель Феофан Затворник. 2010b. Слова на Господские, Богородичные и торжественные дни. М., Отчий дом: 424 с.

35. Святитель Феофан Затворник. 1898. Собрание писем святителя Феофана. Вып. 2. М., Афонский русский Пантелеимонов монастырь: 240 с.

36. Святитель Филарет (Дроздов). 1885. Собрание мнений и отзывов Филарета, митрополита Московского и Коломенского, по учебным и церковно-государственным вопросам. Т. 1. СПб., Синодальная типография: $531 \mathrm{c.}$

37. Скола А., Маренго Д., Лопес Х. П. 2005. Богословская антропология. М., Христианская Россия: 384 с.

38. Соловьев В.С. 1989. Чтения о богочеловечестве. Сочинения в двух томах. Философская публицистика. М., Правда: 736 с.

39. Сухова Н. Ю. 2010. Записки святителей Иннокентия (Борисова) и Филарета (Дроздова) о Духовных школах. Филаретовский альманах, 6: 53-54.

40. Тертышников Г., архимандрит. 2008. Симфония по творениям святителя Феофана, Затворника Вышенского. М., ДАРЬ: 640 с.

41. Флоренский П.А. 2002. Столп и утверждение истины: Опыт православной теодицеи в двенадцати письмах. М., Лепта: 812 с.

42. Флоровский Г.В. 1922. В мире исканий и блужданий. Русская мысль, IV. URL: http://anthropology.rchgi.spb.ru/florovsky2.htm (дата обращения: 26 декабря 2019).

43. Флоровский Г.В. 1991. Пути русского богословия. Вильнюс (репринт: Париж, 1937): 599 c.

44. Хомяков А.С. 1995. Церковь одна. Сочинения богословские. Публикуется по изданию: Полное собрание сочинений Алексея Степановича Хомякова. Сочинения богословские. Издание пятое. СПб., Наука: 480 с.

45. Хоружий С.С. 2001. Антропология православия. В кн.: Новая философская энциклопедия (в 4 томах) под редакцией B.C. Стёпина. URL: http://philosophy.niv.ru/doc/encyclopedia/new-philosophical/articles/120/antropologiyahristianskaya.htm (дата обращения: 25 декабря 2019).

46. Хоружий С.С. 2003. Богословие соборности и богословие личности: Симфония двух путей православного Богомудрия. URL: http://synergia-isa.ru/biblioteka /biblioteka-horuzhij/\#H (дата обращения: 25 декабря 2019).

47. Хоружий С.С. 1994. После перерыва. Пути русской философии. СПб., Алетейя: 448 с.

48. Хохлова А.Б. 2011. Инновационно-эвристическое значение наследия Феофана Затворника для развития современного российского образования: диссертация ... кандидата педагогических наук. Курск: 218 с.

49. Чурсанов С.А. 2014. Лицом к лицу. Понятие личности в православном богословии ХХ века. М., Издательство ПСТГУ, 264 с.

50. Ширяев Г. 2001-2003. Антропология Святителя Феофана Затворника Вышенского. Русское самосознание. № 8: 142-162, № 9: 48-78, № 10: 163-175.

51. «Antropologia theologica»: rationality as a turning point of the Russian orthodox thought Igor Goncharenko, Aleksandr Litvinenko, Olga Nifontova, Irina Strakhova. APPSCONF. 2019. URL: https://www.shs-conferences.org/articles/shsconf/abs/2019/13 /shsconf_appsconf2019_01001 /shsconf_appsconf2019_01001. html (дата обращения: 07.09.2019).

52. Yannaras Ch. 2012. Person, Essence, and Energies [Online] URL: http://synaxisstudy.blogspot.com/2012/04/dr-christos-yannaras-person-essence-and.html (дата обращения: 28 декабря 2019).

\section{References}

1. Aleksenko O.V. 2016. Interpretacija svt. Feofanom Zatvornikom antropologii sv. apostola Pavla [Bishop Theophan 's interpretation of St. Apostle Paul 's anthropology]. M.: 215 p. 
2. Berdjaev N.A. 2007. Aleksej Stepanovich Homjakov [Alexey Stepanovich Homyakov]. URL: https://www.litres.ru/nikolay-berdyaev/aleksey-stepanovich-homyakov/chitatonlayn/page-4/ (data obraschenija: 30 nojabrja 2019).

3. Val'verde K. 2000. Filosofskaja antropologija [Philosophical anthropology]. Per. s isp. G. Vdovinoj. Pod red. E. Gejnrihsa. M., Hristianskaja Rossija: 412 p.

4. Vladimir (Sabodan), mitropolit Kievskij i vseja Ukrainy. 1997. Jekkleziologija v otechestvennom bogoslovii [Ecclesiology in domestic theology]. K.: 512 p.

5. Gavrjushin N.K., 1997. Russkaja religioznaja antropologija [Russian religious anthropology]. Tom 1. URL: https://azbyka.ru/otechnik/antropologiya-i-asketika/russkaja-religioznajaantropologija-tom-1/ (data obrashhenija: 18 dekabrja 2019).

6. Dobrohotov A.L. 2000. Filosofija i hristianstvo [Philosophy and Christianity]. Sbornik dokladov konferencii «Hristianstvo i filosofija». M., Otdel religioznogo obrazovanija i katehizacii RPC: 5-21.

7. Dronov Mihail, protoierej. 1998. Jekzistencija i opyt v pravoslavnom myshlenii nakanune XXI veka [Existence and experience in Orthodox thinking on the eve of the 21st century]. Al'fa i Omega. № 4: 255-271.

8. Ermichev A.A. 2014. Imena i sjuzhety russkoj filosofii [Names and stories of Russian philosophy]. SPb., Nauka: 710 p.

9. Zen'kovskij V.V. 1991a. Istorija russkoj filosofii [History of the Russian philosophy]. Vol. 1. Part 1. L., Ego: 221 p.

10. Zen'kovskij V.V. 1991b. Istorija russkoj filosofii [History of the Russian philosophy]. Vol. 1. Part 2. L., Ego: 280 p.

11. Zen'kovskij V.V. 1991v. Istorija russkoj filosofii [History of the Russian philosophy]. Vol. 2. Part 1. L., Ego: 256 p.

12. Zen'kovskij V.V. 1991g. Istorija russkoj filosofii [History of the Russian philosophy]. Vol. 2. Part 2. L., Ego: 269 p.

13. Ivanov M.S. 2000. Blagodat' [Grace] In: Pravoslavnaja jenciklopedija [Orthodox encyclopedia]. Under the General editorship of Patriarch Kirill of Moscow and all Russia. M., of Church-scientific center «Pravoslavnaja jenciklopedija». URL: http:/www.pravenc.ru/ (data obrashhenija: 19 nojabrja 2019).

14. Ioann (Ziziulas), mitropolit Pergamskij. 2002. Lichnostnost' i bytie [Personality and being]. M., Pravoslavnyj Svjato-Tihonovskij bogoslovskij institute, 10: 22-50.

15. Karsavin L.P. 1992. Religiozno-filosofskie sochinenija [Religious and philosophical compositions]. Vol. 1. M., Renessans: 325 p.

16. Kleman O. 1992. Lichnost' po ucheniju russkih filosofov XIX-XX vekov [Personality by the teaching of Russian philosophers of the 19th-20th centuries]. Pravoslavnaja obshhina, 6 (12): 52-62.

17. Kornilij (Zajcev), ieromonah. 2016. Uchenie svjatitelja Feofana, Zatvornika Vyshenskogo, o dushe cheloveka v kontekste pravoslavnoj antropologii [The doctrine of Saint Theophan, The recluse of vyshensk, about the human soul in the context of Orthodox anthropology]. Sergiev Posad: 28 p.

18. Korol'kov A.A. 2005. Duhovnaja antropologija [Spiritual anthropology]. SPb., Izdvo SPbGU: $323 \mathrm{p}$.

19. Losskij V.N. 2003. Bogovidenie [Vision of God]. M., Publ. AST: 64 p.

20. Mefodij (Zinkovskij), ieromonah. 2014. Bogoslovie lichnosti v XIX-XX vv. [Theology of personality in the XIX-XX centuries]. SPb., Publ. Olega Obyshko: 320 p.

21. Nizhnikov S.A. 2012. Metafizika very v russkoj filosofii: monografija [Metaphysics of Faith in Russian Philosophy: Monograph]. M., INFRA-M: 313 p. 
22. Nikulina E.N. 2016. Antropologo-pedagogicheskie vozzrenija svjatitelja Feofana Zatvornika [Anthropological-pedagogical views of Saint Theophan the Recluse]: avtoreferat dis. ... kandidata pedagogicheskih nauk: 13.00.01. In-t srategii razvitija obrazovanija RAO. M., $31 \mathrm{p}$.

23. Novikov D.V. 2000a. Hristianskoe uchenie o cheloveke [Christian teaching of man]. Chelovek. 5: 116-126.

24. Novikov D.V. 2000b. Hristianskoe uchenie o cheloveke [Christian teaching of man]. Chelovek, 6: 97-108.

25. Novikov D.V. 2001. Hristianskoe uchenie o cheloveke [Christian teaching of man]. Chelovek, 1: 119-127.

26. Svjatitel' Feofan Zatvornik. 2008a. Voploshhennoe domostroitel'stvo. Opyt hristianskoj psihologii v pis'mah [Incarnate domostroitelstvo. Christian Psychology Experience in Letters]. M., Pravilo Very: $462 \mathrm{p}$.

27. Svjatitel' Feofan Zatvornik. 1997. Nastavlenija v duhovnoj zhizni [Instructions in spiritual life]. M., Otchij dom: 104 p.

28. Svjatitel' Feofan Zatvornik. 2010a. Nachertanie hristianskogo nravouchenija [Outline of Christian morals]. M., Pravilo very: 689 p.

29. Svjatitel' Feofan Zatvornik. 2007a. Pis'ma o raznyh predmetah very i zhizni. Sobranie pisem [Letters about different subjects of faith and life. Collection of letters]. M., Pravilo very: $592 \mathrm{p}$.

30. Svjatitel' Feofan Zatvornik. 2007b. Pis'ma o hristianskoj zhizni [Letters about the Christian life]. M., Pravilo very: 448 p.

31. Svjatitel' Feofan Zatvornik. 2004. Poslanie svjatogo apostola Pavla k Efesjanam [The Message of St. Paul to Ephesians]. M., Pravilo Very: 644 p.

32. Svjatitel' Feofan Zatvornik. 2005. Pravoslavie i nauka. Rukovodstvennaja kniga izrechenij i pouchenij [Orthodoxy and science. The Book of Words and Teachings]. M., Danilovskij blagovestnik: $680 \mathrm{p}$. Very: $700 \mathrm{p}$.

33. Svjatitel' Feofan Zatvornik. 2008b. Rukopisi iz kel'i [Manuscripts from a cell]. M., Pravilo

34. Svjatitel' Feofan Zatvornik. 2010b. Slova na Gospodskie, Bogorodichnye i torzhestvennye dni [Words on the Lord, Virgin and solemn days]. M., Otchij dom: 424 p.

35. Svjatitel' Feofan Zatvornik. 1898. Sobranie pisem svjatitelja Feofana [Collection of letters of Saint Theophan]. Release 2. M., Afonskij russkij Panteleimonov monastyr': 240 p.

36. Svjatitel' Filaret (Drozdov). 1885. Sobranie mnenij i otzyvov Filareta, mitropolita Moskovskogo i Kolomenskogo, po uchebnym i cerkovno-gosudarstvennym voprosam. [Collection of opinions and opinions of Filaret, Metropolitan of Moscow and Kolomna, on educational and Church-state issues]. Vol. 1. SPb., Sinodal'naja tipografija: $531 \mathrm{p}$.

37. Skola A., Marengo D., Lopes H.P. 2005. Bogoslovskaja antropologija [Theological anthropology]. M., Hristianskaja Rossija: 384 p.

38. Solov'ev B.C. 1989. Chtenija o bogochelovechestve [Lectures on Divine Humanity]. Sochinenija v dvuh tomah. Filosofskaja publicistika. M., Pravda: 736 p.

39. Suhova N.Ju. 2010. Zapiski svjatitelej Innokentija (Borisova) i Filareta (Drozdova) o Duhovnyh shkolah. Filaretovskij al'manah, 6: 53-54.

40. Tertyshnikov G., arhimandrit. 2008. Simfonija po tvorenijam svjatitelja Feofana, Zatvornika Vyshenskogo [Symphony on the creations of Saint Theophan, Zatvornik of Voshensky]. M., DAR: 640 p.

41. Florenskij P.A. 2002. Stolp i utverzhdenie istiny: Opyt pravoslavnoj teodicei v dvenadcati pis'mah [Pillar and Statement of Truth: The Experience of Orthodox Theodicea in Twelve Letters]. M., Lepta: $812 \mathrm{p}$.

42. Florovskij G.V. 1922. V mire iskanij i bluzhdanij [In a world of searching and wandering]. Russkaja mysl', IV: 135. URL: http://anthropology.rchgi.spb.ru/florovsky2.htm (data obrashhenija: 26 dekabrja 2019).

43. Florovskij G.V. 1991. Puti russkogo bogoslovija [Ways of Russian theology]. Vil'njus (reprint: Parizh, 1937): 599 p.

44. Homjakov A.S. 1995. Cerkov' odna. Sochinenija bogoslovskie [One church. Theological compositions]. SPb., Nauka: 480 p.

45. Horuzhij S.S. 2001. Antropologija pravoslavija [Orthodoxy anthropology]. (Stat'ja dlja jenciklopedii). Novaja filosofskaja jenciklopedija (v 4 tomah) pod redakciej V.S. Stjopina. URL: 
http://philosophy.niv.ru/doc/encyclopedia/new-philosophical/articles/120/antropologiya-hristianskaya .htm (data obrashhenija: 25 dekabrja 2019).

46. Horuzhij S.S. 2003. Bogoslovie sobornosti i bogoslovie lichnosti: Simfonija dvuh putej pravoslavnogo Bogomudrija [Theology of Cathedral and Theology of Personality: Symphony of the Two Ways of Orthodox God]. URL: http://synergia-isa.ru/biblioteka /biblioteka-horuzhij/\#H (data obrashhenija: 25 dekabrja 2019).

47. Horuzhij S.S. 1994. Posle pereryva. Puti russkoj filosofii [After a break. Ways of the Russian philosophy]. SPb., Aletejja: 448 p.

48. Hohlova A.B. 2011. Innovacionno-jevristicheskoe znachenie nasledija Feofana Zatvornika dlja razvitija sovremennogo rossijskogo obrazovanija [Innovation-heuristic significance of Feofan Zatvornik 's legacy for the development of modern Russian education]: dissertacija ... kandidata pedagogicheskih nauk. Kursk: $218 \mathrm{p}$.

49. Chursanov S.A. 2014. Licom k licu. Ponjatie lichnosti v pravoslavnom bogoslovii XX veka [Face to face. The Concept of Personality in 20th Century Orthodox Theology]. M., Publ. PSTGU: 264 p.

50. Shirjaev G. 2001-2003. Antropologija Svjatitelja Feofana Zatvornika Vyshenskogo [Anthropology of Saint Theophan the Zatvornik of Voshensky]. Russkoe samosoznanie. № 8: 142-162, № 9: 48-78, № 10: 163-175.

51. Goncharenko I., Litvinenko A., Nifontova O., Strakhova I. 2019. «Antropologia theologica»: rationality as a turning point of the Russian orthodox thought. APPSCONF. URL: https://www.shsconferences.org/articles/shsconf/abs/2019/13/shsconf_appsconf2019_01001/shsconf_app sconf2019_01001.html (data obrashhenija: 25 dekabrja 2019).

52. Yannaras Ch. 2012. Person, Essence, and Energies. URL: http: //synaxisstudy.blogspot.com/2012/04/dr-christos-yannaras-person-essence-and.html (data obrashhenija: 25 dekabrja 2019).

\section{Ссылка для цитирования статьи For citation}

Ольхов П.А. Гончаренко И.В. 2020. Концептуализация человека в христианской философии (опыт еп. Феофана (Говорова)). NOMOTHETIKA: Философия. Социология. Право. 45 (1): 172-182. DOI 10.18413/2712-746X-2020-45-1-172-182

Olkhov P.A. Goncharenko I.V. 2020. Conceptualization of man in Christian philosophy (experience St. Theophan the Recluse). NOMOTHETIKA: Philosophy. Sociology. Law series. 45 (1): 172-182 (in Russian). DOI 10.18413/2712-746X-2020-45-1-172-182 